\title{
An Assessment of Biological Potency and Molecular Characteristics of Different Innovator and Noninnovator Interferon-Beta Products
}

\author{
Anthony Meager,, Carl Dolman,, Paula Dilger, ${ }_{1}^{1}$ Chris Bird, ${ }^{1}$ Gavin Giovannoni, \\ Huub Schellekens, ${ }^{3}$ Robin Thorpe, ${ }^{1}$ and Meenu Wadhwa ${ }^{1}$
}

Approved innovator products and their noninnovator "copy" versions are likely to vary in their quality, eg, physicochemical characteristics and biological activity, with important implications for clinical efficacy and safety. Therefore, it is important to study and thoroughly evaluate the noninnovator products in comparison with approved products at the preclinical and clinical stages. We have obtained 4 noninnovator interferon (IFN)$\beta$-1a products currently marketed in Latin America and Iran and compared these with approved IFN- $\beta$-1a products (Avonex and Rebif) obtained from the same geographical regions with respect to biological potency, estimated by in vitro bioassays, and molecular characteristics, assessed by immunoblotting and high-performance liquid chromatography. In this article, we present our data showing that the noninnovator IFN- $\beta$-1a products can vary considerably in their biological potency. In addition, we showed that all IFN- $\beta-1$ a products formulated with human serum albumin contained variable amounts of higher-molecular-weight aggregates of IFN- $\beta-1 \mathrm{a}$ and adducts with human serum albumin, these being more prevalent in 2 noninnovator IFN- $\beta$-1a products where biological potency was reduced compared with approved IFN- $\beta-1$ a products. Additionally, significant lot-to-lot variability was observed for one of the noninnovator products. Taken together, the results of this study highlight the need for not only thorough in vitro characterization, but also preclinical and clinical assessment to ensure patient safety and efficacy.

\section{Introduction}

Since the approval of Recombinant DNA-derived huSman insulin in 1982 by the U.S. Food and Drug Administration, many recombinant DNA-derived biotherapeutic products including erythropoietin, granulocyte-colonystimulating factor, and interferon- $\alpha$ (IFN- $\alpha$ ) have gained regulatory approval and revolutionized the therapy of various diseases. However, many patents for the first generation of biotherapeutics have expired (or are expiring) and this has led to the marketing of "copies" or noninnovator versions worldwide. The latter products are intended to provide a similar benefit/risk balance as that of an innovator (reference) product but at a reduced cost, thereby widening the accessibility of these medicines to patients. Unlike chemical generic drugs, which are identical to their branded counterparts, protein products, which are often manufactured by recombinant DNA technology, are complex and heteroge- neous and possess characteristics that are highly dependent on the processes used for their manufacture. This includes the expression system, raw materials, protein production, isolation and purification processes, as well as the formulation and storage of the final product. As a consequence, even if the proteins are produced using the same gene sequence, it is highly likely that the quality of the products differs considerably, with potential impact on clinical efficacy and safety (Schellekens 2004; Combe and others 2005; Mellstedt and others 2008).

In Europe, a legislative and regulatory framework has been established for approval of patent-expired biotherapeutics. The European Medicines Agency has adopted the terminology of similar biological medicinal products or "biosimilar" products and issued detailed regulatory guidance as well as product-specific guidelines for facilitating approval of these products (European Medicines Agency 2005, 2006a, 2006b). Consequently, several biosimilars have

\footnotetext{
${ }^{1}$ Cytokine and Growth Factor Section, Biotherapeutics Group, National Institute for Biological Standards and Control, Hertfordshire, United Kingdom.

${ }^{2}$ Department of Neurology, Blizard Institute of Cell and Molecular Science, Barts and The London School of Medicine and Dentistry, Queen Mary University of London, London, United Kingdom.

${ }^{3}$ Department of Pharmaceutical Sciences and Innovation Studies, Utrecht University, Utrecht, The Netherlands.
} 
been approved to date and are now being marketed in the EU (Wadhwa and Thorpe 2009). For authorization in the EU, the noninnovator product must be highly similar in quality, efficacy, and safety to the innovator (reference) product marketed in Europe. Therefore, besides the stringent testing at the quality level (as expected for a novel biotherapeutic), a comprehensive comparability exercise of both the noninnovator and the reference product is imperative to show that the products are highly similar from the quality perspective and demonstrate similar efficacy and safety profile. The need for preclinical studies and comparative clinical trials of both products to provide assurance on the efficacy and safety of the noninnovator relative to the reference product is clearly stipulated (European Medicines Agency 2006b). Although similarity at the quality level may result in a possible reduction in preclinical and clinical data needed, the amount of data required for approval is specific for the product and determined on a case-by-case basis. Consequently, for all approved biosimilars so far, clinical trials albeit relatively small sized have been conducted. Further, the manufacturer is committed to ongoing pharmacovigilance and monitoring of patients for any adverse effects.

Several countries including Japan and Canada have developed appropriate regulatory guidance on the basis of the EU biosimilarity approach. Recently, the World Health Organization adopted a guideline for similar biotherapeutic products using the biosimilar concept to harmonize the requirements for product licensing worldwide, thus promoting that "copy" biotherapeutic products available globally maintain high quality and deliver appropriate efficacy and safety to patients (WHO 2009). However, "copy" or "me-too" products are already marketed in many countries worldwide; the basis of their approval, although unclear, is unlikely to be based on a strict, rigorous comparability testing as expected for biosimilars in EU. In some cases, these products may have been approved following an assessment of publicly available data on the innovator's product without any requirement for preclinical or clinical data and monitoring of undesirable clinical impact such as signs of reduced efficacy and adverse effects in patients. Such products, although often referred to as biosimilars, are not "true" biosimilars from the EU perspective. However, it is imperative that a clear distinction is made between the 2 different categories of noninnovator products as this has considerable implications for efficacy and safety.

Among the list of biotherapeutics affected by patent expiry is IFN- $\beta$, which is indicated for the treatment of the relapsing form of multiple sclerosis, RRMS (Goodin 2005; Clerico and others 2007; Lam and others 2008). The mechanism underlying the effect of IFN- $\beta$ in RRMS remains elusive, although the effectiveness of IFN- $\beta$ therapy has been proven (Jacobs and others 1996; PRISMS Study Group 1998; Goodin 2005; Clerico and others 2007; Lam and others 2008). Although a single human protein, 3 recombinant IFN- $\beta$ innovator products varying in structure and formulation have been approved in North America and Europe for treating patients with RRMS. Betaseron (IFN- $\beta-1 b$ ) is a nonglycosylated IFN- $\beta$ Ser17 mutein produced in Escherichia coli, in which the cysteine residue at position 17 is replaced by a serine to prevent formation of intermolecular disulphide bonds and potential aggregation. Avonex and Rebif (both IFN- $\beta-1 a)$ are glycosylated IFN- $\beta$ preparations, with the natural sequence produced in Chinese hamster ovary $(\mathrm{CHO})$ cells, and these are formulated differently and administered using different routes and frequency (Goodin 2005; Clerico and others 2007; Lam and others 2008). To date, no "true" IFN- $\beta$ biosimilar product has been approved worldwide. However, a number of "copy" (but not biosimilar) IFN- $\beta$ products are manufactured and marketed principally in economically constrained countries, often in competition with the innovator IFN- $\beta$ products. These include products such as Blastoferon (Biosidus), Clausen (Laboratorio Clausen), Emaxem (Probiomed), Xerfelan (Landsteiner Scientific)_all claiming similarity to Rebif and Jumtab (Probiomed) and Cinnovex (Cinnagen), which claim similarity to Avonex.

How these products differ from the innovator products in terms of their quality (eg, active component, impurities, and potency) and the extent to which they differ is largely unknown. As such differences could be associated with adverse clinical sequelae, it is important to study and thoroughly evaluate these products in comparison with innovator products at the preclinical stage.

In this study, we have compared 4 IFN- $\beta$ - 1 a noninnovator "copy" products currently marketed in Latin America and Iran with approved IFN- $\beta-1$ a products (Avonex and Rebif) obtained from the same geographical regions with respect to their biological potency, estimated by in vitro bioassays, and molecular characteristics, assessed by immunoblotting and high-performance liquid chromatography (HPLC).

\section{Materials and Methods}

\section{Materials}

IFN- $\beta$-1a products were supplied to NIBSC either directly from the manufacturer and routine supply chains, or under the auspices of the EU NABIMS Framework 6 Project. All products were maintained at the labeled storage conditions and tested within the label expiry. Products tested are Jumtab, Clausen, Blastoferon, Cinnovex, Avonex, and Rebif. For the purpose of this study, they have been coded as A to F, and different batches have been assigned numerical values (Table 1). All products except for A1-A5 contain human serum albumin (HSA) in their formulation.

\section{Antiviral assays}

Antiviral assays (AVAs) for IFN potency estimations were performed by the cytopathic effect reduction method (Meager 2002, 2003) using either human 2D9 glioblastoma (Däubener and others 1994) or human A549 adenocarcinoma (ATCC CCL-185) cell lines. In brief, 2D9 were seeded in 96-well microtiter plates in RPMI1640 medium (Sigma Chemical) plus $6 \%(\mathrm{v} / \mathrm{v})$ heat-inactivated fetal bovine serum (HIFBS) and incubated overnight at $37^{\circ} \mathrm{C}$ in a $5 \% \mathrm{CO}_{2}$-gassed incubator to form confluent monolayers. A549 were treated similarly, except culture medium was Dulbecco's modified Eagle's medium (DMEM) (Sigma Chemical) plus 10\% (v/v) HIFBS. Appropriate off-plate dilutions of IFN- $\beta-1$ a products and of the third international standard (IS) of human IFN- $\beta$ [glycosylated, CHO cell derived, coded 00/572, 40,000 international units (IU)/ampoule] (Meager and Gaines Das 2005) were prepared in cell growth medium and then serially diluted in 2-fold steps in duplicate rows in the assay plates. After a 24-h incubation at $37^{\circ} \mathrm{C}$, the culture medium was replaced by $0.1 \mathrm{~mL}$ maintenance medium $(2 \%$ HIFBS) containing 
Table 1. A List of Different Interferon- $\beta 1$ a Products Tested and Their Mean Potency Derived from Different Bioassays

\begin{tabular}{|c|c|c|c|c|c|c|c|}
\hline Product & Code & $\begin{array}{l}\text { Product } \\
\text { name }\end{array}$ & $\begin{array}{l}\text { Country } \\
\text { of origin }\end{array}$ & Form & $\begin{array}{c}\text { IFN- } \beta-1 a \\
\text { content }(\mu g)\end{array}$ & $\begin{array}{c}\text { Stated } \\
\text { potency/dose (MIU) }\end{array}$ & $\begin{array}{l}\text { Potency }^{\mathrm{a}} \\
\text { (MIU/dose) }\end{array}$ \\
\hline \multirow[t]{9}{*}{ Innovator } & A1 & Avonex & Mexico & Liquid & 30 & 6 & $8.25(76)$ \\
\hline & $\mathrm{A} 2$ & Avonex & Uruguay & Liquid & 30 & 6 & 7.77 (68) \\
\hline & A3 & Avonex & Uruguay & Liquid & 30 & 6 & $7.95(34)$ \\
\hline & $\mathrm{A} 4$ & Avonex & Argentina & Liquid & 30 & 6 & 7.75 (73) \\
\hline & A5 & Avonex & Europe & Liquid & 30 & 6 & $8.39(82)$ \\
\hline & A6 & Avonex & Europe & Powder & 30 & 6 & 8.42 (68) \\
\hline & B1 & Rebif & Uruguay & Liquid & 44 & 12 & 8.55 (49) \\
\hline & B2 & Rebif & Uruguay & Liquid & 44 & 12 & $8.31(34)$ \\
\hline & B3 & Rebif & Argentina & Liquid & 44 & 12 & 8.47 (56) \\
\hline \multirow{7}{*}{ Noninnovator } & $\mathrm{C} 1$ & Jumtab & Mexico & Powder & 30 & 6 & $4.56(81)$ \\
\hline & D1 & Blastoferon & Argentina & Liquid & 44 & 12 & $11.74(55)$ \\
\hline & E1 & Clausen & Uruguay & Liquid & 44 & 12 & $12.71(62)$ \\
\hline & E2 & Clausen & Uruguay & Liquid & 44 & 12 & 13.89 (35) \\
\hline & $\mathrm{F} 1$ & Cinnovex & Iran & Powder & 30 & 6 & $4.92(70)$ \\
\hline & $\mathrm{F} 2$ & Cinnovex & Iran & Powder & 30 & 6 & 5.12 (77) \\
\hline & F3 & Cinnovex & Iran & Powder & 30 & 6 & $1.95(74)$ \\
\hline
\end{tabular}

Different products are coded as A to F. The numbers A1-A6 denote different batches of the same product; the same applies to all the other products listed.

All products with the exception of A1-A5 contain albumin in their formulation.

${ }^{a}$ Potency values in the table are geometric means of all values obtained using different potency assays. Values in parentheses denote number of estimations.

IFN, interferon; MIU, million international unit.

encephalomyocarditis virus (EMCV) in all wells, except "no virus" cell controls, and the plates were incubated again for $24 \mathrm{~h}$ at $37^{\circ} \mathrm{C}$ before processing using amido-blue black stain (Meager 2003). The stain was eluted with $0.1 \mathrm{M}$ sodium hydroxide and the absorbances were read at $620 \mathrm{~nm}$. Dose-responses were plotted graphically as absorbance versus reciprocal IFN dilution. Potency estimates for IFN- $\beta$ test preparations against the $00 / 572$ IS of IFN- $\beta$ were made using an in-house parallel line displacement method and expressed as $\mathrm{IU} / \mathrm{mL}$ (or IU/dose). Geometric mean potencies and $95 \%$ confidence limits were calculated using GraphPad Prism 4 software. Specific activities of IFN- $\beta$ test preparations were calculated from the manufacturers' given IFN- $\beta$ protein content on the label and expressed as IU/mg IFN- $\beta$ protein.

\section{Reporter gene assays}

Reporter gene assays were performed using a transfected HEK 293 cell line harboring the secreted alkaline phosphatase cDNA linked to the IFN-stimulated response element promoter (LaFleur and others 2001; Meager and others 2005). Cells were cultured in DMEM (4.5 mg D-glucose/mL) plus $10 \%(\mathrm{v} / \mathrm{v})$ HIFBS, routine antibiotics, and G418 $(50 \mu \mathrm{g} / \mathrm{mL})$, trypsinized, seeded in 96-well microtiter assay plates at $2.5 \times 10^{4}$ cells $/$ well in $0.1 \mathrm{~mL}$ colorless DMEM $(1.0 \mathrm{mg}$ D-glucose $/ \mathrm{mL}$ ) maintenance medium (as above but without G418), and incubated overnight at $37^{\circ} \mathrm{C}$. Appropriate offplate dilutions of IFN- $\beta$ - 1 a products and the third IS of human IFN- $\beta$, coded 00/572 (Meager and Gaines Das 2005), were prepared in colorless DMEM medium and then serially diluted in 2-fold steps in duplicate rows in separate 96-well plates before transfer to the assay plates. Dilutions of 00/572 were added on each plate of every assay. Following incubation of plates at $37^{\circ} \mathrm{C}$ for $48 \mathrm{~h}, 0.05 \mathrm{~mL}$ aliquots of cell supernatants from all wells were transferred to positionally identical wells of new 96-well microtiter plates and $0.05 \mathrm{~mL}$ p-nitrophenyl phosphate substrate $(1 \mathrm{mg} / \mathrm{mL}$ in $10 \%$ ethanolamine buffer, $\mathrm{pH}$ 9.8) was added to all wells. The plates were incubated for $2-3 \mathrm{~h}$ at room temperature and the absorbance was read at $405 \mathrm{~nm}$ using an ELISA reader. Doseresponses were plotted graphically as absorbance versus reciprocal IFN dilution. Potency estimates for IFN- $\beta$ test preparations against the $00 / 572$ IS of IFN- $\beta$, geometric mean potencies (GMPs) and 95\% confidence limits, and specific activities of individual test preparations were calculated as described for AVAs.

\section{Sodium dodecyl sulfate-polyacrylamide gel electrophoresis and immunoblotting}

Sodium dodecyl sulfate (SDS)-polyacrylamide gel electrophoresis was carried out using the Mini Protean-3 Gel Electrophoresis System (Biorad). Human IFN- $\beta$-1a preparations were heated at $100^{\circ} \mathrm{C}$ in sample buffer for $5 \mathrm{~min}$ and electrophoresed under nonreducing conditions ( $\sim 20 \mathrm{ng}$ of IFN- $\beta$-1a protein was loaded/track) using 4\%-20\% Tris $/ \mathrm{HCl}$ gradient polyacrylamide gels (Biorad Ready Gels) for $1 \mathrm{~h}$. The separated proteins were electrophoretically transferred to nitrocellulose membranes and the membranes were blocked using a solution of $5 \%(\mathrm{w} / \mathrm{v})$ milk powder in phosphate-buffered saline (PBS) for at least $30 \mathrm{~min}$ on a rotary shaker. The blots were then incubated with a commercially available mouse monoclonal antibody specific for human IFN- $\beta$ (at a concentration of $1 \mu \mathrm{g} / \mathrm{mL}$ or $1 / 500$ dilution in PBS/milk; MAB 814; R\&D Systems) overnight at room temperature on a rotary shaker, washed extensively with PBS/milk, and further incubated with horse radish peroxidase-conjugated anti-mouse IgG (Sigma Chemical; at a dilution of $\sim 1 / 2000$ in PBS/milk solution) for $1 \mathrm{~h}$ on a rotary shaker. The blots were finally washed 5 times with 
PBS/0.05\% Tween 20 and the immunoreactive protein bands were visualized using enhanced chemiluminesence reagents obtained from Amersham. To check for cross-reactivity, HSA was electrophoresed in some experiments to reflect the amounts present in the various IFN- $\beta-1$ a products that had been formulated with HSA.

\section{Reverse-phase HPLC}

Reverse-phase HPLC was performed using a temperaturecontrolled HPLC system (Gilson) comprising a 231XL injector equipped with a $200-\mu \mathrm{L}$ loop, two 306 pumps, a gradient mixer, a 119 dual wavelength detector, a column heater, and Gilson chromatography system software (Unipoint 5.1). The separation column used for reverse phase was a Millipore Delta-Pak $5 \mu \mathrm{m}$ C4-300 $\AA, 150 \times 3.9 \mathrm{~mm}$. The solution used for mobile phase A was 30\% acetonitrile (BDH; Hypersolv) containing $0.05 \%$ trifluoroacetic acid (Fluka; $>99 \%$ for HPLC 91707) and 70\% water (HPLC grade, Thermo No. 51140) and for mobile phase B was $60 \%$ acetonitrile containing $0.05 \%$ trifluoroacetic acid and $40 \%$ water.

The system was equilibrated at a flow rate of $1 \mathrm{~mL} / \mathrm{min}$ until a stable baseline was achieved. Aliquots of $100 \mu \mathrm{L}$ of different IFN- $\beta$-1a preparations (stock concentration of products $\mathrm{C}$ and $\mathrm{F}, 30 \mu \mathrm{g} / \mathrm{mL} ; \mathrm{A}, 60 \mu \mathrm{g} / \mathrm{mL} ; \mathrm{B}, \mathrm{D}$, and $\mathrm{E}$, $88 \mu \mathrm{g} / \mathrm{mL}$ ) were injected undiluted from a sample rack (chilled to $4{ }^{\circ} \mathrm{C}$ ) onto the column (heated to $35^{\circ} \mathrm{C}$ ) and eluted with the following gradient: $0-2 \mathrm{~min}, 65 \% \mathrm{~A}, 35 \% \mathrm{~B} ; 2$ 22 min, linear gradient from $35 \%$ to $85 \%$ B; $22-24$ min, wash step of $100 \%$ B; $24-26 \mathrm{~min}$, returning to start conditions of
$35 \% \mathrm{~B}$, with the run ending after $32 \mathrm{~min}$. Eluted peaks were detected using UV absorbance at 214 and $280 \mathrm{~nm}$.

\section{Results}

\section{Biological potency of different IFN- $\beta$ products}

Different assays were used for assessing the biological activity of the different products. As the AVAs are currently in use as a potency assay in various laboratories, we have employed these assays using the 2D9/EMCV or A549/ EMCV combination, which, although highly sensitive, are laborious, multistep, and complicated. In contrast, the reporter gene assay has a simple and easy procedure, short incubation time, and a read-out based on IFN- $\beta$-stimulated soluble alkaline phosphatase production (Meager and others 2005); such reporter gene assays have become popular for assessment of biological activity of different IFN proteins.

Antiviral assays. Using 2D9 AVAs, individual potency estimates $(n=14-44)$ from 4 to 7 independent assays were derived for each product; the percentage of coefficient of variation of estimates ranged from $10.6 \%$ to $21.5 \%$. The individual potencies obtained with each product were expressed as "million IU (MIU)/dose" and represented as symbols in the scatter plot (Fig. 1). All approved innovator IFN- $\beta$-1a products had similar GMPs and showed consistency between the batches. For example, the GMP of product A varied between 7.84 and $8.58 \mathrm{MIU} /$ dose, whereas that of product B varied between 8.35 and 9.16 $\mathrm{MIU} /$ dose. Together, the potencies ranged from 7.84 to

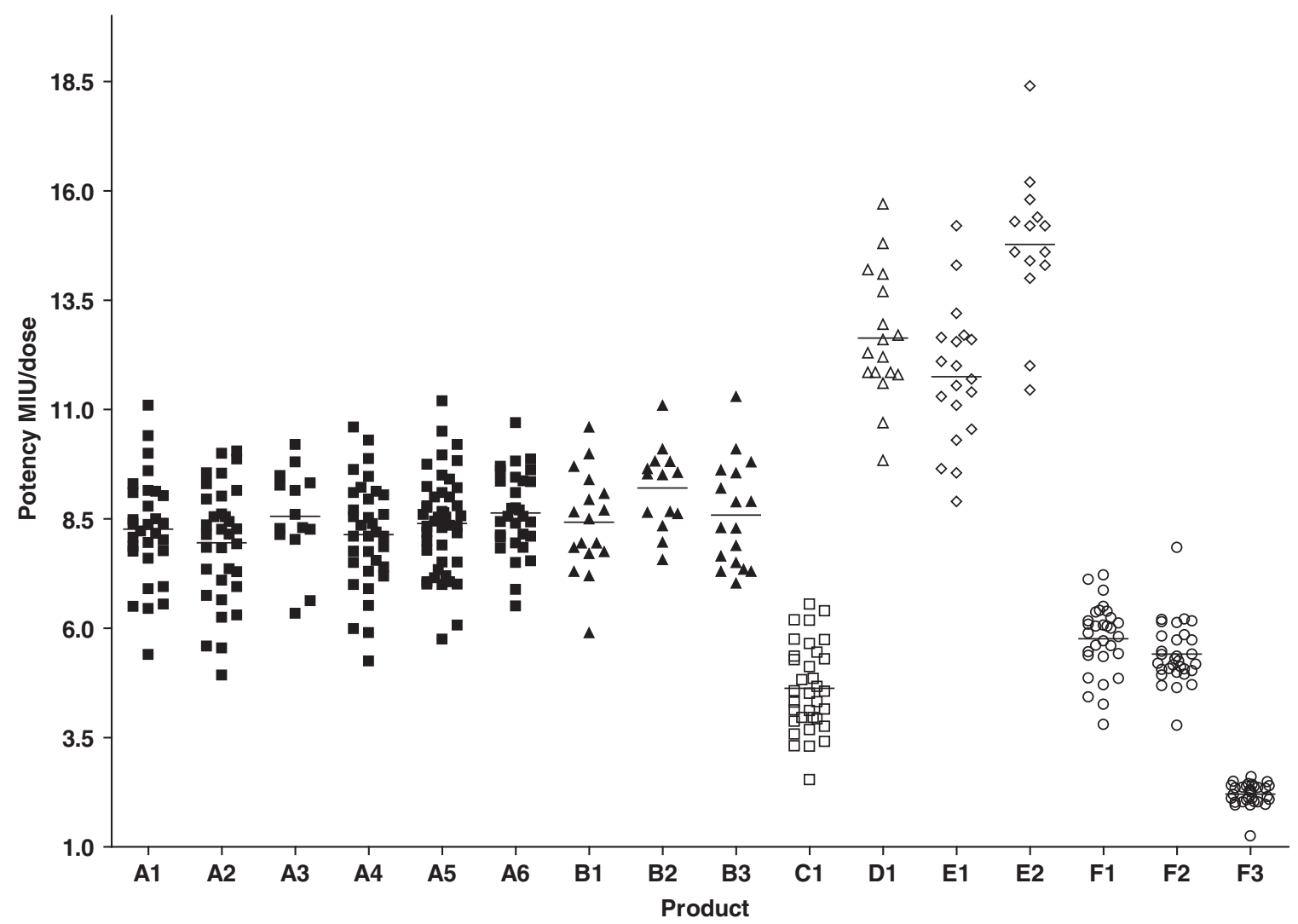

FIG. 1. Potency estimates of different IFN- $\beta$-1a products (coded A-F) obtained using 2D9 antiviral assays. For details on number of assays, refer to Table 2. IFN, interferon. 
Table 2. Potency and Specific Activity Values for Interferon- $\beta-1 \mathrm{~A}$ Products Derived Using Different Bioassays

\begin{tabular}{|c|c|c|c|c|c|c|}
\hline \multirow{2}{*}{$\begin{array}{l}\text { Product } \\
\text { Code }\end{array}$} & \multirow[b]{2}{*}{ Name } & \multicolumn{4}{|c|}{ Potency $^{\mathrm{a}}$ (MIU/dose) } & \multirow{2}{*}{$\begin{array}{c}\text { Specific activity }(\mathrm{MIU} / \mathrm{mg}) \\
\text { All assays }\end{array}$} \\
\hline & & 2D9 AVA & A549 AVA & ISRE SEAP RGA & All assays & \\
\hline A1 & Avonex & $8.17(30)$ & $9.83(13)$ & $7.77(33)$ & $8.25(76)$ & 275 \\
\hline A2 & Avonex & $7.84(33)$ & $8.16(9)$ & $7.56(26)$ & 7.77 (68) & 259 \\
\hline A3 & Avonex & 8.49 (14) & ND & $7.60(20)$ & $7.95(34)$ & 265 \\
\hline A4 & Avonex & $8.05(34)$ & $7.54(13)$ & 7.49 (26) & 7.75 (73) & 258 \\
\hline A5 & Avonex & $8.32(44)$ & $10.19(5)$ & $8.25(33)$ & $8.39(82)$ & 280 \\
\hline A6 & Avonex & $8.75(25)$ & $9.75(5)$ & $8.08(33)$ & $8.42(68)$ & 281 \\
\hline B1 & Rebif & $8.58(30)$ & $9.85(4)$ & $8.51(28)$ & $8.55(49)$ & 194 \\
\hline $\mathrm{B} 2$ & Rebif & $9.16(14)$ & ND & $7.76(20)$ & $8.31(34)$ & 189 \\
\hline B3 & Rebif & $8.51(17)$ & $8.78(7)$ & $8.38(32)$ & $8.47(56)$ & 192 \\
\hline $\mathrm{C} 1$ & Jumtab & $4.52(34)$ & $4.82(13)$ & $4.55(34)$ & $4.56(81)$ & 152 \\
\hline D1 & Blastoferon & 12.55 (17) & $10.63(7)$ & $11.57(31)$ & $11.74(55)$ & 267 \\
\hline E1 & Clausen & $11.65(19)$ & $14.73(11)$ & $12.71(32)$ & $12.71(62)$ & 289 \\
\hline E2 & Clausen & $14.68(14)$ & ND & $13.38(21)$ & $13.89(35)$ & 316 \\
\hline $\mathrm{F} 1$ & Cinnovex & $5.70(30)$ & $4.88(5)$ & $4.34(35)$ & $4.92(70)$ & 164 \\
\hline F2 & Cinnovex & $5.37(31)$ & ND & $4.96(46)$ & $5.12(77)$ & 171 \\
\hline F3 & Cinnovex & $2.19(31)$ & ND & 1.79 (43) & $1.95(74)$ & 65 \\
\hline
\end{tabular}

Different products are coded as A to F. The numbers A1-A6 denote different batches of the same product; the same applies to all the other products listed.

All products with the exception of A1-A5 contain albumin in their formulation.

${ }^{a}$ Potency and specific activity values are geometric means. Specific activity values have been calculated from potencies derived from "all assays" and rounded-up to the nearest whole number. Values in parentheses denote number of estimations.

AVA, antiviral assay; ISRE, interferon-stimulated response element; ND, not done; SEAP RGA, secreted alkaline phosphatase reporter gene assay.

9.16 MIU/dose for the innovator products. In contrast, the GMPs of the noninnovator IFN- $\beta$-1a products were fairly broad and variable, ranging from 2.19 to $14.68 \mathrm{MIU} /$ dose (Table 2). Although GMP appeared to be reasonably consistent within batches for the noninnovator product, E, this was not the case for the 3 batches of product F. For the latter, the GMP varied >2-fold from 2.19 to $5.70 \mathrm{MIU} /$ dose; however, the GMPs were fairly similar to that of product C, with a GMP of 4.52 for the batch tested. For both approved and noninnovator IFN- $\beta$ - 1 a products, the potencies using A549 AVAs were found to be in broad agreement with those derived from 2D9 AVAs $(n=2-5)$ conducted for each product (Table 2).

Reporter gene assays. In addition to AVAs, reporter gene assays were performed for each product. Products were titrated a similar number of times $(n=26-35)$ in 5-6 independent assays; the percentage of coefficient of variation of estimates ranged from $7.5 \%$ to $25.8 \%$.

Overall, the potencies were consistent with those derived from AVAs. The GMPs of the approved IFN- $\beta-1$ a products were similar, in the range 7.49-8.51 MIU/dose (Table 2), and in close agreement with those derived from 2D9 cell-based AVAs. As seen with the AVA, differences in potencies were found among the noninnovator IFN- $\beta$-1a products and ranged from 1.79 to $13.38 \mathrm{MIU} /$ dose (Table 2). The GMP of the 3 batches of product $\mathrm{F}$ varied from 1.79 to $4.96 \mathrm{MIU} /$ dose, with F3 showing the lowest GMP, a $>2$-fold variation in GMP as noted in the AVA. In contrast, the GMP for products $\mathrm{D}$ and $\mathrm{E}$ was similar; product D had a GMP of 11.57 MIU/ dose and product E showed a GMP of 12.71 and $13.38 \mathrm{MIU} /$ dose for the 2 batches tested (Table 2). Combining all results from all assays ( $n=49-81$ for individual products) yielded potency values largely reflecting those of the separate AVA and reporter gene assay (Table 2 ).
Based on calculations of product's specific activity on potency values that were obtained from all assays and the manufacturer's stated IFN- $\beta$ - 1 a protein content/dose (as indicated on the package insert or packaging), it was evident that there were clear differences among the products. Products $\mathrm{D}$ and $\mathrm{E}$ had specific activities that were comparable to the specific activity range for the approved IFN- $\beta$-1a product A (Table 1) but higher than that of the other innovator product, product B. The specific activity of the different batches of product A was also higher than that of product B. In contrast, the specific activities of the 2 noninnovator IFN$\beta$-1a products, products $C$ and $F$, were much lower (Table 2).

\section{Immunochemical analysis of different IFN- $\beta$ products}

To ascertain the homogeneity of the IFN- $\beta$ preparations, immunoblotting (which only detects IFN- $\beta$ ) using nonreducing SDS gel was performed. A representative immunoblot of different IFN- $\beta-1$ a products is shown in Fig. 2. Immunoblotting of different IFN- $\beta$ - 1 a products showed a major band of IFN- $\beta$ monomer migrating between 17 and $24 \mathrm{kDa}$ for all products and another band of $\sim 38 \mathrm{kDa}$, probably representing a small amount of IFN- $\beta$ dimer in a majority of batches tested. All tested batches of product A without albumin (A1-A5) contained only these 2 bands. However, IFN- $\beta$ - 1 a products containing HSA, irrespective of whether they are innovator or noninnovator products, showed, in addition to the IFN- $\beta$ monomer $(17-24 \mathrm{kDa})$ or the dimer $(\sim 38 \mathrm{kDa})$, several other bands, mostly of higher apparent molecular weights. Products D and E and a batch of product A (A6), which contained HSA, showed a very similar profile with no evidence of bands $>76 \mathrm{kDa}$. However, this profile was clearly different from that seen with other 


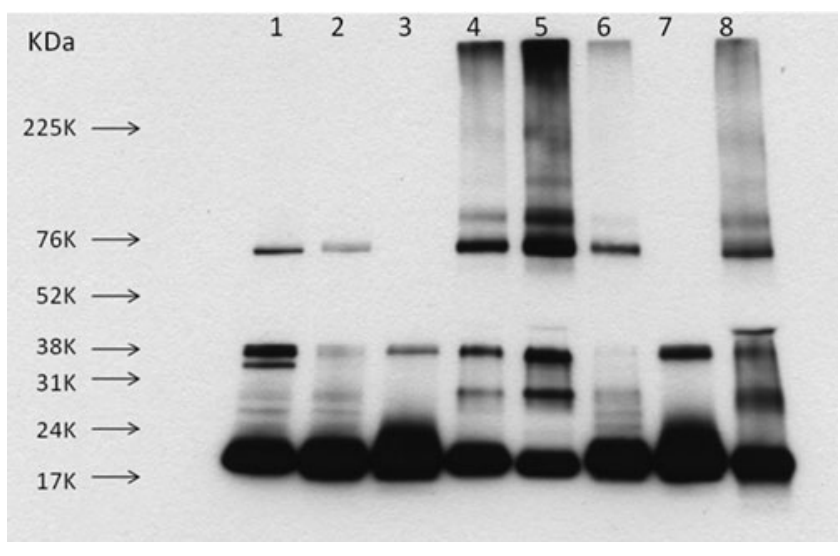

FIG. 2. An immunoblot of different IFN- $\beta-1$ a products (coded A-F) using a commercially available IFN- $\beta$-specific monoclonal antibody showing variable composition of the different products. Different IFN- $\beta-1$ a products $(\sim 20 \mathrm{ng}$ of IFN- $\beta$-1a protein/track) were electrophoresed under nonreducing conditions using $4 \%-20 \%$ Tris $/ \mathrm{HCl}$ gradient polyacrylamide gels for $1 \mathrm{~h}$, followed by immunoblotting as described in the Materials and Methods section. Products are as follows: track 1, B2; track 2, E2; track 3, A3; track 4, F2; track 5, F3; track 6, A6 (+HSA); track 7, A5 (no HSA); track 8, $\mathrm{C} 1$. To control for specificity, HSA in amounts reflecting the levels present in different IFN- $\beta$-1a products was tested for reactivity with the IFN- $\beta$-specific monoclonal antibody in some experiments. No reactivity was evident (data not shown). HSA, human serum albumin.

HSA-formulated products, products C and F. Significantly, the number of bands and their intensity, especially a band of $\sim 76 \mathrm{kDa}$, were greatest in the noninnovator products with the lowest specific activities, ie, products $C$ and $F$, although also evident in innovator products containing HSA (Table 1). It is likely that the observed additional bands were indicative of the presence of IFN- $\beta$-related multimers, IFN- $\beta$-albumin adducts, and/or possibly aggregates in these products because HSA alone in amounts reflecting levels present in the various IFN- $\beta-1$ a products was completely unreactive with the IFN- $\beta$-specific mAb used for detection purposes.

\section{Reverse-phase HPLC}

For assessing the purity of the IFN- $\beta$ products and for assessing the presence of aggregates (under nondenaturing conditions), reverse-phase HPLC was utilized. When separated by reverse-phase HPLC, IFN- $\beta$ - 1 a products formulated without HSA showed a discrete protein peak, representative of the IFN- $\beta-1$ a monomer eluted at $16.0-16.4 \mathrm{~min}$ with only an occasional very minor faster eluting peak (Fig. 3a). In contrast, IFN- $\beta$-1a products formulated with HSA had, in most cases, 1 or more peaks of higher molecular weight besides the major IFN- $\beta-1$ a peak. HSA eluted at $1.6-1.8 \mathrm{~min}$. For instance, product $C$ appeared to have 3 additional peaks accounting for $\sim 19 \%$ total non-HSA protein (Fig. 3d). Further, the major peak in this case appeared broader than in other products. A similar profile was obtained with product F, which besides 2 additional peaks revealed a broad peak with a shoulder representative of the IFN- $\beta$-1a monomer (Fig. 3e). This contrasted with the profiles evident for products E (Fig. 3c) and B (Fig. 3f), which showed a rather narrow and discrete major IFN- $\beta-1$ a peak. Product D was similar in its profile to $\mathrm{E}$ but contained an additional very minor peak (data not shown).

\section{Discussion}

Although biosimilar IFN- $\beta$-1a products as defined by the European Medicines Agency and WHO have not been approved anywhere in the world as yet, a number of alternative copy products of innovator IFN- $\beta-1$ a products are available in South America and Asia. In this study, we have for the first time compared the biological activity and molecular characteristics of some of the available noninnovator IFN- $\beta$ - 1 a products with those of approved innovator IFN- $\beta$ 1 a products. This analytical evaluation revealed considerable heterogeneity among IFN- $\beta$ - 1 a products produced by different manufacturing processes around the world. Key differences have been noted in the composition, concentration, and activity of manufactured IFN- $\beta-1$ a products, but how these differences impact clinically can only be assessed by conducting appropriate clinical studies for efficacy and safety including immunogenicity.

Immunochemical analysis by SDS-polyacrylamide gel electrophoresis followed by immunoblotting revealed that all IFN- $\beta$-1a products contained in large proportion the monomeric IFN- $\beta-1 a$, migrating at the expected molecular weight of $\sim 18-24 \mathrm{kDa}$. In the absence of HSA, only one much weaker band of $38 \mathrm{kDa}$ was visible, probably representing a minor amount of IFN- $\beta$-1a dimer. However, in the presence of HSA used as an excipient in the formulation of a majority of products, slower migrating, multiple bands of varying number and intensity were observed. As the anti-IFN- $\beta$ mAb does not react with HSA, these bands must represent IFN- $\beta$ polypeptides, probably as adducts with breakdown products of HSA and aggregates-dimers and higher-molecularweight oligomers - of IFN- $\beta$. That these bands were most numerous and intense, particularly an apparent tetrameric aggregate at $\sim 76 \mathrm{kDa}$, in the noninnovator products with the lowest specific activities, $\mathrm{C} 1$ and F1, suggests an inverse correlation between their formation [presence] and biological activity. Further supporting evidence of adduct and aggregate formation for products formulated with HSA was obtained with reverse-phase HPLC. Additional peaks of unknown protein composition to the major IFN- $\beta$ peak were observed in both approved and noninnovator products, but again were greatest in number and peak height in those noninnovator products with the lowest specific activity.

We therefore assessed the biological activity of different IFN- $\beta$-1a products in both AVA and reporter gene assay. For this, we used the third IS for IFN- $\beta$ (glycosylated; $\mathrm{CHO}$ cell derived, coded 00/572, assigned potency of 40,000 IU/ ampoule) for calibration of bioassays. This IS has been shown to be suitable as a reference standard in bioassays for measuring the potency of clinical grade IFN- $\beta$-1a products (Meager and Gaines Das, 2005). We found that the calculated potency for each product was consistent between these distinct assay types. In both AVA and reporter gene assay, noninnovator IFN- $\beta-1$ a products $\mathrm{C} 1$ and F1 had comparatively lower biological potencies than was stated on their respective labels (below the label strength of $6 \mathrm{MIU}$ ) and relatively low specific activities. A batch-to-batch variation was also noted for product F. In contrast, noninnovator IFN- $\beta$ - 1 a products D1 and E1 had relatively higher potencies, but close to their stated label strength of 12 MIU. Their specific activities 

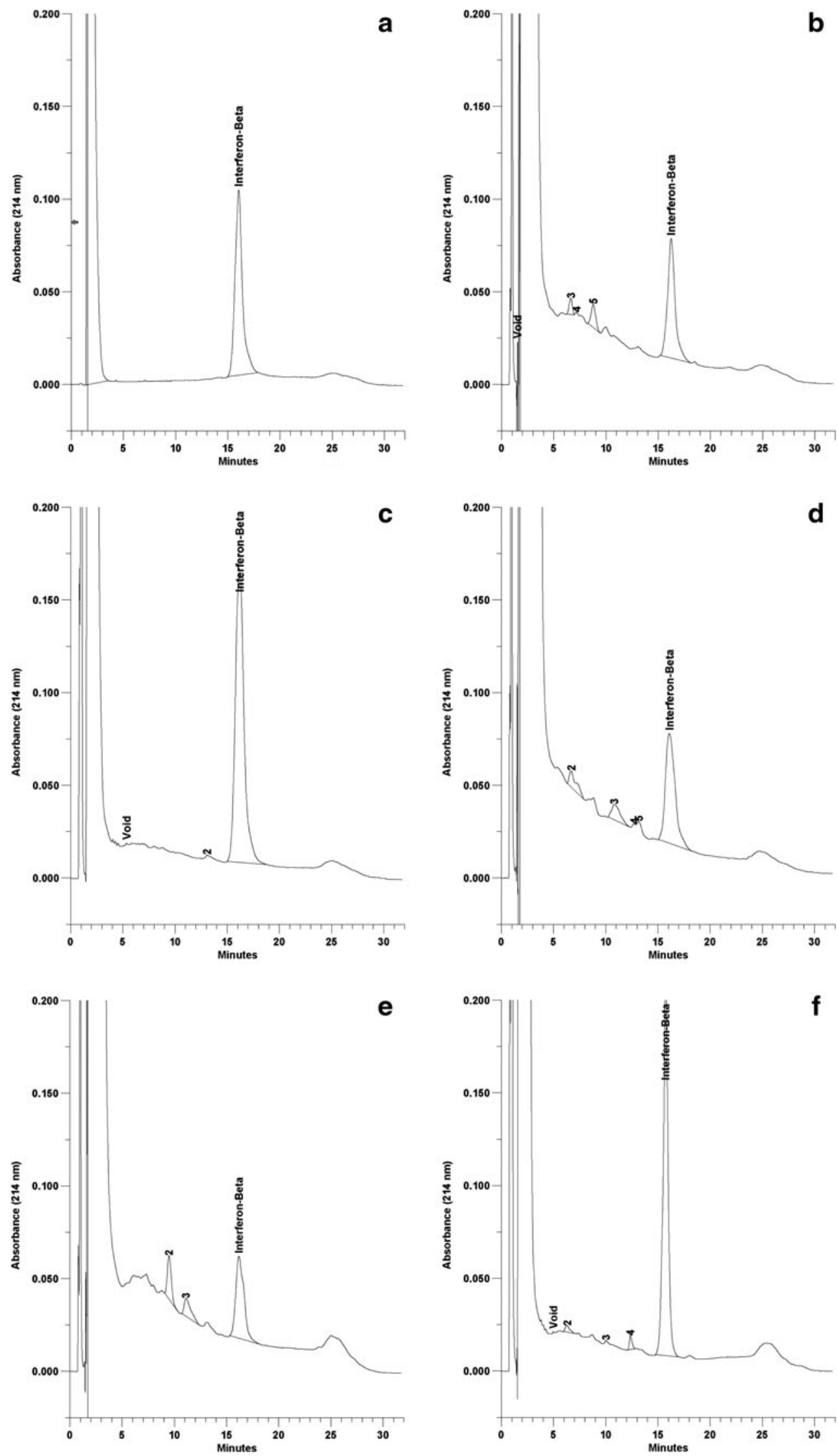

FIG. 3. Typical reverse phase (RP)-high-performance liquid chromatography profiles of different IFN- $\beta$ - 1 a products (coded A-F). Key to products shown in the different panels are as follows: (a) A5 (no HSA), (b) A6 (+HSA), (c) E1, (d) C1, (e) F3, and (f) B2. Of note are the differences in the major peak representing the IFN- $\beta$ monomer and the presence of other highmolecular-weight peaks in the different products. 
matched those obtained with different batches (A1-A6) of an approved IFN- $\beta$ - 1 a product, product $A$, which is marketed in different countries. However, although this approved IFN$\beta$-1a product was distinguishable on the basis of protein content from B1 to B3, which represented batches of the other approved product, the potencies of $\mathrm{A}$ and $\mathrm{B}$ products were quite similar. The potencies of A1-A6 all exceeded label strength of $6 \mathrm{MIU}$, whereas those of B1-B3, although similar in numerical terms, were below the label strength of 12 MIU. The specific activities of the latter were also lower given that this product contained more IFN- $\beta-1$ a protein (Table 1 ). These observations may be due to differences in analytical methods used by the respective manufacturers of these 2 approved products, eg, methods used for determining IFN$\beta-1$ a protein concentration or estimation of potency. Although manufacturers of noninnovator products may also apply different methods for assessing potency, our results, which are derived from assays calibrated with the third IS for IFN- $\beta$ throughout the study, strongly suggest that some noninnovator products are likely to be less efficacious than their innovator counterparts. Therefore, robust clinical studies are required to evaluate the efficacy of these noninnovator products.

As the noninnovator products tested in this study are not biosimilar products per se (as defined by the European Medicines Agency and WHO), considerable heterogeneity in the structural and physicochemical characteristics between these products and their innovator counterparts is not unexpected. However, the differences noted between the noninnovator products (that are claiming similarity to approved innovator products) and the innovator products clearly appear to have the potential to affect their efficacy and safety, particularly from the perspective of unwanted immunogenicity (Wadhwa and Thorpe 2007, 2009). Consistent with this, a comparison of noninnovator erythropoietin products (available outside of the United States and Europe) with the innovator product, Eprex, showed significant differences in physicochemical and biological characteristics, which, in some instances, may be associated with severe adverse effects, eg, pure red cell aplasia (Keithi-Reddy and others 2008; Fotiou and others 2009; Schellekens 2009), identified previously in patients treated with Eprex (Casadevall and others 2002).

The level of immunogenicity can clearly be markedly different even for products based on the same amino acid sequence. This is because immunogenicity is governed by a multitude of factors. These include the structure of the protein (native or modified sequence, structural similarity with the native protein), the composition and formulation of the final product, the presence of impurities, aggregates, clipped, degradation products, the dose and duration of treatment, the frequency and route of administration (especially when administered as multiple doses over prolonged duration), the properties of the protein, the patient's genetic predisposition to produce antibodies, immune status, and the disease indication (Wadhwa and Thorpe 2009; Sauerborn and others 2010). Consequently, it is difficult to predict the immunogenicity of a therapeutic on the basis of preclinical data alone.

For IFN- $\beta$ products, the incidence of antibody formation varies depending on the IFN- $\beta$ product used for treatment. Prevalences of neutralizing antibodies (Nabs) in patients treated with Avonex, Rebif, and Betaseron have been reported as $2 \%-6 \%, 12 \%-28 \%$, and $28 \%-47 \%$, respectively
(Bertolotto and others 2004); some variation in this is expected because of the different assays that have been used to measure Nabs in various studies (Sominanda and others 2007; Deisenhammer 2009). It has been suggested that the physicochemical properties of IFN- $\beta-1 b$ (Betaseron), including its poor solubility and propensity to aggregate, may contribute to Nab formation (Runkel and others 1998; Basu and others 2006). The high occurrence of Nabs in Betaseronor Rebif-treated patients may also be partly attributed to subcutaneous administration. Equally, it is possible that HSA, which is implicated in adduct and aggregate formation, contributes to increased immunogenicity (Runkel and others 1998; Basu and others 2006) as evidenced by the reduction in immunogenicity upon removal of HSA from approved innovator products (Giovannoni and others 2009). This is consistent with evidence from previous studies with IFN- $\alpha 2 \mathrm{a}$, which also showed that removal of HSA from the formulation led to decreased immunogenicity (Hochuli 1997; Ryff 1997).

Although the impact of adduct and aggregate formation of the noninnovator IFN- $\beta-1$ a products (tested here) on immunogenicity cannot be reliably predicted at the preclinical stage, it can be speculated that immunogenicity is most likely to occur with these products as has been noted with approved HSA-containing innovator IFN- $\beta-1$ a products. Preliminary data have shown that $58 \%$ of 61 patients treated with product $\mathrm{D}$ developed binding antibodies; $8 \%$ of patients were Nab positive (Kauffman and others 2008). However, as all noninnovator IFN- $\beta$-1a products tested contain HSA, which has a propensity to form aggregates, there is an increased risk to patients for developing antibodies following therapy with these products. Evidence shows that persistent anti-IFN- $\beta$ NAbs are associated with reduced pharmacodynamics, loss of bioactivity, and diminished clinical response as assessed by magnetic resonance imaging or increased relapses or disease progression (Bertolotto and others 2003; McKay and others 2006; Namaka and others 2006; Pachner and others 2006, 2009; Farrell and Giovannoni 2007; Scagnolari and others 2007; Deisenhammer 2009; van de Voort and others 2009). Further, the developed NAbs also crossreact and inhibit the biological activity of different IFN- $\beta$ products-a switch over to a different IFN- $\beta$ product has been recently shown to have no significant effect on NAb titers (Gneiss and others 2009). Such a scenario would therefore lead to progressive disease with considerable implications for management of disease and quality of life of these patients.

Based on the results of this study, it is likely that patients treated with noninnovator IFN- $\beta$-1a products, especially $\mathrm{C}$ and $\mathrm{F}$ with the lowest specific activities and greatest observable adducts and aggregates, are at heightened risk of IFN- $\beta$ NAb development, leading to diminished efficacy and likely treatment failures. Further, because of the potential clinical impact of the cross reactivity of NAbs across different approved IFN- $\beta$ products, switching of patients to another IFN- $\beta$ product (noninnovator or an innovator product associated with a high incidence of antibody formation) without the guidance of a physician and a thorough benefit-risk assessment should not be considered.

In conclusion, we have shown that noninnovator IFN- $\beta-1 a$ products can vary considerably in their biological potency. Those with high specific activity and label strength in accord with approved IFN- $\beta-1$ a products were shown to contain 
small amounts of adducts with HSA and some highermolecular-weight aggregates. However, in noninnovator products where these adducts/aggregates were most prevalent (eg, C1 and F1), biological potency appeared to be reduced. The clinical efficacy and safety of such products may therefore be compromised with implications for MS patients being treated with these products. Our study strongly suggests that noninnovator products should be very carefully evaluated at both the preclinical and clinical stage of development for efficacy and safety prior to their therapeutic use.

\section{Acknowledgment}

The authors are grateful to EU NABIMS Framework 6 Project for provision of some of the products used in this study.

\section{Author Disclosure Statement}

Huub Schellekens has been involved in meetings and publications sponsored by Merck-Serono, Bayer, and Biogen and his research is partly and indirectly funded by MerckSerono. Gavin Giovannoni has received consulting fees from Bayer-Schering Healthcare, Biogen-Idec, Genzyme, GlaxoSmithKline, Merck-Serono, Novartis, Protein Discovery Laboratories, Teva-Aventis, Vertex Pharmaceuticals, and UCB Pharma; lecture fees from Bayer-Schering Healthcare, Biogen-Idec, Pfizer, Teva-Aventis, Vertex Pharmaceuticals; and grant support from Bayer-Schering Healthcare, BiogenIdec, GW Pharma, Merck-Serono, Merz, Novartis, TevaAventis, and UCB Pharma. All authors from NIBSC, where all of the work specified in this study has been conducted, have no conflicts to declare.

\section{References}

Basu A, Yang K, Wang M, Liu S, Chintala R, Palm T, Zhao H, Peng P, Wu D, Zhang Z, Hua J, Hsieh MC, Zhou J, Petti G, Li X, Janjua A, Mendez M, Liu J, Longley C, Zhang Z, Mehlig M, Borowski V, Viswanathan M, Filpula D. 2006. Structurefunction engineering of interferon-beta- $1 \mathrm{~b}$ for improving stability, solubility, potency, immunogenicity, and pharmacokinetic properties by site-selective mono-PEGylation. Bioconjug Chem 17:618-630.

Bertolotto A, Deisenhammer F, Gallo P, Sölberg Sørensen P. 2004. Immunogenicity of interferon beta: differences among products. J Neurol 251 (Suppl. 2):II15-II24.

Bertolotto A, Gilli F, Sala A, Capobianco M, Malucchi S, Milano E, Melis F, Marnetto F, Lindberg RL, Bottero R, Di Sapio A, Giordana MT. 2003. Persistent neutralizing antibodies abolish the interferon beta bioavailability in MS patients. Neurology 60:634-639.

Casadevall N, Nataf J, Viron B, Kolta A, Kiladjian JJ, MartinDupont P, Michaud P, Papo T, Ugo V, Teyssandier I, Varet B, Mayeux P. 2002. Pure red cell aplasia and anti-erythropoietin antibodies against human erythropoietin in patients treated with recombinant erythropoietin. N Engl J Med 346:469-475.

Clerico M, Contessa G, Durelli L. 2007. Interferon-beta1-a for the treatment of multiple sclerosis. Expert Opin Biol Ther 7:535542.

Combe C, Tredree RL, Schellekens H. 2005. Biosimilar epoetins: an analysis based on recently implemented European medicines evaluation agency guidelines on comparability of biopharmaceutical proteins. Pharmacotherapy 25(7):954-962.
Däubener W, Waganat N, Pilz K, Seghrouchni S, Fischer HG, Haddin U. 1994. A new, simple, bioassay for human IFN- $\gamma$. J Immunol Methods 168:39-47.

Deisenhammer F. 2009. Neutralizing antibodies to interferonbeta and other immunological treatments for multiple sclerosis: prevalence and impact on outcomes. CNS Drugs 23: 379-396.

European Medicines Agency. Guideline on similar biological medicinal products. 2005. Available at www.emea.europa.eu/pdfs/human/biosimilar/043704en.pdf

European Medicines Agency. Guideline on similar biological medicinal products containing biotechnology-derived proteins as active substance: quality issues. 2006a. Available at www.emea.europa.eu/pdfs/human/biosimilar/4934805en .pdf

European Medicines Agency. Guideline on similar biological medicinal products containing biotechnology-derived proteins as active substance: non-clinical and clinical issues. 2006b. Available at www.emea.europa.eu/pdfs/human/biosimilar/ 4283205en.pdf

Farrell RA, Giovannoni G. 2007. Measuring and management of anti-interferon beta antibodies in subjects with multiple sclerosis. Mult Scler 13:567-577.

Fotiou F, Aravind S, Wang PP, Nerapusee O. 2009. Impact of illegal trade on the quality of epoetin alfa in Thailand. Clin Ther 31:336-346.

Giovannoni G, Barbarash O, Casset-Semanaz F, King J, Metz L, Pardo G, Simsarian J, Sørensen PS, Stubinski B; Rebif New Formulation Study Group. 2009. Safety and immunogenicity of a new formulation of interferon beta-1a (Rebif New Formulation) in a phase IIIb study in patients with relapsing multiple sclerosis: 96-week results. Mult Scler 15:219-228.

Gneiss C, Koudouovoh-Tripp PM, Ropele S, Gotwald T, Ehling R, Lutterotti A, Aichner F, Ladurner G, Eggers C, Schautzer F, Künz B, Millonig A, Aspeck E, Reindl M, Berger T, Fazekas F, Deisenhammer F. 2009. Influence of interferon-beta therapy switching on neutralizing antibody titres: results from the Austrian Switch Study (ASS). Mult Scler 15:1481-1488.

Goodin DS. 2005. Treatment of multiple sclerosis with human beta interferon. Int MS J 12:96-108.

Hochuli E. 1997. Interferon immunogenicity: technical evaluation of interferon- $\alpha 2$ a. J Interferon Cytokine Res 17 (Suppl. 1):S15-S21.

Jacobs LD, Cookfair DL, Rudick RA, Herndon RM, Richert JR, Salazar AM, Fischer JS, Goodkin DE, Granger CV, Simon JH, Alam JJ, Bartoszak DM, Bourdette DN, Braiman J, Brownscheidle CM, Coats ME, Cohan SL, Dougherty DS, Kinkel RP, Mass MK, Munschauer FE 3rd, Priore RL, Pullicino PM, Scherokman BJ, Whitham RH, and others. 1996. Intramuscular interferon beta-1a for disease progression in relapsing multiple sclerosis. Ann Neurol 39:285-294.

Kauffman M, Papouchodo M, Gonzalez E, Sterin Prync A, Vidal A, Diez R, Ferro H. 2008. Early post-marketing pharmacovigilance of Blastoferon: an interferon beta 1a biosimilar. Drug Saf 31(10):895.

Keithi-Reddy SR, Kandasamy S, Singh AK. 2008. Pure red cell aplasia due to follow-on epoetin. Kidney Int 74:1617-1622.

LaFleur DW, Nardelli B, Tsareva T, Mather D, Feng T, Semenuk M, Taylor K, Buergin M, Chinchilla D, Roschke V, Chen G, Ruben SM, Coleman TA, Moore PA. 2001. Interferon-kappa, a novel type I interferon expressed in human keratinocytes. J Biol Chem 276:39765-39771.

Lam S, Wang S, Gottesman M. 2008. Interferon- $\beta 1 b$ for the treatment of multiple sclerosis. Expert Opin Drug Metab Toxicol 4:1111-1117. 
McKay F, Schibeci S, Heard R, Stewart G, Booth D. 2006. Analysis of neutralizing antibodies to therapeutic interferon-beta in multiple sclerosis patients: a comparison of three methods in a large Australian cohort. J Immunol Methods 310:20-29.

Meager A. 2002. Biological assays for interferons. J Immunol Methods 261:21-36.

Meager A. 2003. Assays for antiviral activity. Methods Mol Biol 249:121-134.

Meager A, Gaines Das R. 2005. Biological standardization of human interferon beta: establishment of a replacement world health organization international biological standard for human glycosylated interferon beta. J Immunol Methods 306:1-15.

Meager A, Visvalingam K, Dilger P, Bryan D, Wadhwa M. 2005. Biological activity of interleukins-28 and -29: comparison with type I IFNs. Cytokine 31:109-118.

Mellstedt H, Niederwieser D, Ludwig H. 2008. The challenge of biosimilars. Ann Oncol 19(3):411-419.

Namaka M, Pollitt-Smith M, Gupta A, Klowak M, Vasconcelos M, Turcotte D, Gong Y, Melanson M. 2006. The clinical importance of neutralizing antibodies in relapsing-remitting multiple sclerosis. Curr Med Res Opin 22:223-239.

Pachner AR, Cadavid D, Wolansky L, Skurnick J. 2009. Effect of anti-IFN \{beta\} antibodies on MRI lesions of MS patients in the BECOME study. Neurology 73:1485-1492.

Pachner A, Narayan K, Pak E. 2006. Multiplex analysis of expression of three IFN- $\beta$ genes in antibody-positive MS patients. Neurology 66:444-446.

PRISMS (Prevention of Relapses and Disability for Interferon beta-1a subcutaneously in Multiple Sclerosis) Study Group. 1998. Randomised doulble-blind placebo-controlled study of interferon beta-1a in relapsing multiple sclerosis. Lancet 352:1498-1504.

Runkel L, Meier W, Pepinsky RB, Karpusas M, Whitty A, Kimball K, Brickelmaier M, Muldowney C, Jones W, Goelz SE. 1998. Structural and functional differences between glycosylated and non-glycosylated forms of human interferon- $\beta$ (IFN- $\beta$ ). Pharm Res 15:641-649.

Ryff J-C. 1997. Clinical investigation of the immunogenicity of interferon- $\alpha 2 a$. J Interferon Cytokine Res 17 (Suppl. 1):S29S33.

Sauerborn M, Brinks V, Jiskoot W, Schellekens H. 2010. Immunological mechanism underlying the immune response to recombinant human protein therapeutics. Trends Pharmacol Sci 31(2):53-59.

Scagnolari C, Duda P, Bagnato F, De Vito G, Alberelli A, Lavolpe V, Girardi E, Durastanti V, Trojano M, Kappos L, Antonelli G. 2007. Pharmacodynamics of interferon beta in multiple sclerosis patients with or without serum neutralizing antibodies. J Neurol 254:597-604.

Schellekens H. 2004. How similar do "biosimilars" need to be? Nat Biotechnol 22(11):1357-1359.

Schellekens H. 2009. Biosimilar therapeutics-what do we need to consider? NDT Plus 2 (Suppl. 1):i27-i36.

Sominanda A, Rot U, Suoniemi M, Deisenhammer F, Hillert J, Fogdell-Hahn A. 2007. Interferon beta preparations for the treatment of multiple sclerosis patients differ in neutralizing antibody seroprevalence and immunogenicity. Mult Scler 13:208-214.

van der Voort LF, Visser A, Knol DL, Oudejans CB, Polman CH, Killestein J. 2009. Lack of interferon-beta bioactivity is associated with the occurrence of relapses in multiple sclerosis. Eur J Neurol 16:1049-1052.

Wadhwa M, Thorpe R. 2007. Unwanted immunogenicity: implications for follow-on biologicals. Drug Inf J 41:1-10.

Wadhwa M, Thorpe R. 2009. The challenges of immunogenicity in developing biosimilar products. IDrugs 12(7):440-444.

WHO. 2009. Guidelines on Evaluation of Similar Biotherapeutic Products (SBPs). Available at www.who.int/entity/ biologicals/publications/trs/areas/biological_therapeutics/ BS2110Dft_guidelines_Final_HK_IK_29July_09.pdf

Address correspondence to: Dr. Meenu Wadhwa Leader, Cytokine and Growth Factor Section Biotherapeutics Group National Institute for Biological Standards and Control Blanche Lane South Mimms Potters Bar Hertfordshire EN6 3QG United Kingdom

E-mail: meenu.wadhwa@nibsc.hpa.org.uk

Received 11 August 2010/Accepted 08 September 2010 